\title{
DETECTION OF RS9939609 POLYMORPHISM OF FTO GENE AND RS324011 POLYMORPHISM OF STAT6 GENE AND SEVERITY DEGREE OF BRONCHIAL ASTHMA ASSOCIATED WITH OBESITY
}

\author{
Alexander Fediv \\ Department of Internal Medicine and Infectious Diseases \\ Higher state education institution of Ukraine "Bukovinan State Medical University" \\ 137 Golovna str., Chernivtsy, Ukraine, 58001 \\ Elena Melnik \\ Department of Internal Medicine and Infectious Diseases \\ Higher state education institution of Ukraine "Bukovinan State Medical University" \\ 137 Golovna str., Chernivtsy, Ukraine, 58001 \\ mlena0102@ukr.net
}

\begin{abstract}
The aim of this research was to analyze the distribution of FTO and STAT6 genes polymorphism in patients with bronchial asthma (BA), associated with obesity ( $\mathrm{Ob})$ depending on the main disease severity degree.

Materials and methods. The study included 117 patients $18-48$ years old, divided in 3 groups. The main group (bronchial asthma, associated with obesity) included 57 patients, two groups of comparison - 30 patients with the diagnosis BA and a normal body weight, and 30 patients with obesity, but without the pathology of the bronchopulmonary system.

The general genomic DNA was extracted from blood according to the standard protocol. The genetic typing was realized by the method of allele-specific amplification with the detection of results in the real time regime using TaqMan-probes, complementary to polymorphic parts of DNA. The detection of deletions in FTO and STAT 6 genes was realized by the method of polymerase chain reaction (PCR) using specific primers.

Results. In the main group, among patients with BA and Ob, carriers of T/T genotype were 36,84\%, T/A - 45,61\%, $\mathrm{A} / \mathrm{A}-17,55 \%$ against $40 \%, 60 \%$ and $0 \%$ respectively in PHP group by FTO gene. Carriers of C/C genotype in the main group were $38,6 \%, \mathrm{C} / \mathrm{T}-35,09 \%, \mathrm{~T} / \mathrm{T}-26,31 \%$ against $40 \%, 55 \%$ and $5 \%$ respectively in PHP group by STAT6 gene. In the main group the light persisting BA was diagnosed in 20,0\% of cases, middle severity - in 60,0 \% and severe - in 20,0\% of patients. In the group of comparison this disease severity was observed in $17,7 \%, 66,5 \%$ and $15,8 \%$ of observations, respectively.

Conclusions. So, among patients with BA, associated with $\mathrm{Ob}$ with the middle and severe course of asthma the percent of heterozygous (T/A) and mutant carriers (A/A) rs9939609 polymorphism of FTO gene is higher than at the light course. The analogous situation is observed at the study of rs324011 polymorphism of STAT6 (C2892T) gene among this category of patients. So, the determination of FTO and STAT6 genes polymorphism in patients with BA, associated with Ob, can be considered as a marker of the more severe course of asthma.
\end{abstract}

Keywords: bronchial asthma, obesity, genes polymorphism.

\section{Introduction}

Bronchial asthma (BA) it is a classic example of a multifactor pathology, realized at the interaction of numerous factors of environment and hereditary predisposition $[1,2]$. Hereditary nature of the disease had been observed already in the last centuries and proved in XX century by hereditary forms of the disease and BA cases in twins. The genetic polymorphism is a base of the phenotypic difference between persons and may cause the hereditary predisposition to different nosologies [3, 4]. Today there is revealed a series of genes, involved in the asthma pathogenesis, that exist in different allele variants (single nucleotide polymorphisms) and favor BA appearance. The detection of "predisposition genes" may favor the purposeful primary prophylaxis in receptive persons [5]. It was established, that at the combination of BA and obesity can be observed the heavier asthma course, worsening of disease control and inadequate response of patients to the treatment [6]. In patients with BA and obesity is formed the difficultly controlled phenotype with manifestations of a dose-dependence or resistance to inhalation CS (ICS) [7]. In the cross research 
by L. Barclay was demonstrated, that the risk of hospitalization in patients with BA and obesity is 5 times higher than in ones with a normal body mass [8]. The feature of BA course at the modern stage is the growth of specific weight of severe forms, including among youth that the high invalidism and lethality are connected with $[9,10]$.

So, mechanisms of the main questions of both BA and obesity are interconnected and need a deeper study at both molecular and genetic level. The most spread method of studying BA genetic mechanisms is the search for disease associations with candidate genes polymorphism. Thus, there are found genes, responsible at the same time for asthma and obesity formation, and also for the synthesis of anti-inflammatory cytokines $[11,12]$. It was established, that at obesity the risk of BA development is 1,4-2,2 times higher than at a normal body mass [13, 14]. Alongside with it the testing of genes-candidates demonstrated that none of them has a preferential value, because the genetic base of the disease has the multifactor nature [15].

\section{Aim of research}

To analyze distributions of rs9939609 polymorphism of FTO gene and rs324011 polymorphism of STAT6 gene in patients with bronchial asthma, associated with obesity, depending on the main disease severity degree.

\section{Materials and methods}

The study included 117 patients $18-48$ years old, divided in 3 clinical groups. The main group (bronchial asthma, associated with obesity - II group) included 57 patients with mean age 38 years old. Among them were 30 women (52 \%) and 27 men (48\%). At the same time two groups of comparison were formed: the first one (1 group) included 30 patients with the diagnosis $\mathrm{BA}$ and normal body mass, the third (III group) - 30 patients with $\mathrm{Ob}$ and without the pathology of the bronchopulmonary system (BMI $>25,0 \mathrm{~kg} / \mathrm{m}^{2}$ ). The control group consisted of 20 practically healthy persons (PHP). The mean duration of bronchial asthma was 8 years $(2-15$ years). The mean duration of obesity was 5 years. For setting the diagnosis, clinical course severity degree were used general clinical, laboratory and instrumental research methods based on GINA recommendations $(2011,2014)$ [16], order of MHP of Ukraine No. 128 "About approval of clinical protocols of medical care for the specialty "Pulmonology" and "Unified clinical protocol of the primary, secondary (specialized) medical care "Bronchial asthma" No. 868 of 08.10.2013.

Genetic studies were realized on the base of the medical-genetic laboratory "Hermedtech", Odessa city (license of MHP of Ukraine No. 196563 of 03.01.2013). The general genomic DNA was extracted from blood according to the standard protocol using the set for DNA extraction from clinical samples “AmpliPrime DNA-sorb-B” (made by AmpliSense, CSRI of epidemiology of MH RF, Russia). The genetic typing was realized by the method of allele-specific amplification with the detection of results in the real time regime using TaqMan-probes, complementary to polymorphic parts of DNA. The detection of deletions in FTO and STAT 6 genes was realized by the method of multiplex polymerase chain reaction (PCR) using specific primers. For FTO (T/A) gene the size of the amplicon for external primers - $321 \mathrm{pb}$, T-allele: $178 \mathrm{pb}$, A-allele: $201 \mathrm{pb}$. For STAT6 (C2892T) gene the size of the amplicon $-275 \mathrm{pb}$.

The obtained results of the study were analyzed using computer packages "STATISTICA" StatSoft Inc. and Excell XP Windows on a personal computer using parametric and non-parametric calculation methods. The distribution of genotypes in the studied sample was verified for the correspondence to Hardy-Weinberg equilibrium using the program Hardy-Weinberg Equilibrium Calculator for 2 Alleles.

\section{Results of researches}

In the process of the research were complexly examined 117 patients, $18-48$ years old, mean age was 33 $\pm 5,2$ y. (Table 1).

Among patients wasn't observed any essential difference by gender. Thus, the male share was $49,2 \%$, female $-50,8 \%$.

Table 1 


\begin{tabular}{|c|c|c|c|c|c|c|c|c|}
\hline & \multicolumn{2}{|c|}{$\begin{array}{l}\text { I group } \\
\text { (BA), } \mathbf{n = 3 0}\end{array}$} & \multicolumn{2}{|c|}{$\begin{array}{c}\text { II group } \\
(\mathbf{B A}+\mathbf{O b}), \mathbf{n}=\mathbf{5 7}\end{array}$} & \multicolumn{2}{|c|}{$\begin{array}{l}\text { III group } \\
(\mathrm{Ob}), \mathbf{n = 3 0}\end{array}$} & \multicolumn{2}{|c|}{$\begin{array}{c}\text { Control group } \\
(\text { PHP) } n=20\end{array}$} \\
\hline & $\mathrm{M}$ & $\mathrm{F}$ & M & $\mathrm{F}$ & M & $\mathrm{F}$ & $\mathrm{M}$ & $\mathrm{F}$ \\
\hline \multicolumn{8}{|l|}{ Sex, $n$} & 11 \\
\hline Mean age, years & \multicolumn{2}{|c|}{$28,5 \pm 4,63$} & \multicolumn{2}{|c|}{$38,52 \pm 3,25$} & \multicolumn{2}{|c|}{$29,52 \pm 7,77$} & \multicolumn{2}{|c|}{$30,33 \pm 5,33$} \\
\hline
\end{tabular}

The expression of T/A polymorphism of FTO gene (rs9939609) and C2892T polymorphism of STAT6 (rs324011) gene was determined in 57 patients with bronchial asthma, combined with obesity, 30 patients with $\mathrm{BA}, 30$ patients with $\mathrm{Ob}$ and 20 practically healthy persons. In the main group, carriers of T/T genotype were $36,84 \%$, T/A $-45,61 \%$, A/A $-17,55 \%$ against $40 \%$, $60 \%$ and $0 \%$ respectively in PHP group by FTO gene. Carriers of C/C genotype in the main group were $38,6 \%, \mathrm{C} / \mathrm{T}-35,09 \%, \mathrm{~T} / \mathrm{T}-26,31 \%$ against $40 \%, 55 \%$ and $5 \%$ respectively in PHP group by STAT6 gene.

Distributions of polymorphisms of selected genes in the main group (in patients with bronchial asthma, combined with obesity) are presented in Table 2.

Table 2

Distributions of polymorphisms of FTO and STAT6 genes in the main group

\begin{tabular}{|c|c|c|c|c|c|c|c|}
\hline & \multicolumn{2}{|c|}{$\begin{array}{l}\text { Genes } \\
\text { Absolute number, n \% }\end{array}$} & \multicolumn{2}{|c|}{ II group $(\mathrm{BA}+\mathrm{Ob}), \mathbf{n}=\mathbf{5 7}$} & \multirow[t]{2}{*}{$\chi^{2}$} & \multirow[t]{2}{*}{$\mathbf{p}$} & \multirow[t]{2}{*}{ p1 } \\
\hline & & $\mathrm{T}$ & 68 & 59,65 & & & \\
\hline & Alleles & & & & & & \\
\hline & & A & 46 & 40,35 & & & \\
\hline \multirow[t]{6}{*}{ FTO } & & $\mathrm{T} / \mathrm{T}$ & 21 & 36,84 & 0,16 & 0,6922 & $>0,05$ \\
\hline & Genotypes & $\mathrm{T} / \mathrm{A}$ & 26 & 45,61 & & & \\
\hline & & $\mathrm{A} / \mathrm{A}$ & 10 & 17,55 & & & \\
\hline & & $\mathrm{C}$ & 64 & 56,14 & & & \\
\hline & Alleles & & & & & & \\
\hline & & $\mathrm{T}$ & 50 & 43,86 & & & \\
\hline \multirow[t]{3}{*}{ STAT6 } & & $\mathrm{C} / \mathrm{C}$ & 22 & 38,60 & 4,71 & 0,03 & $<0,05$ \\
\hline & Genotypes & $\mathrm{C} / \mathrm{T}$ & 20 & 35,09 & & & \\
\hline & & $\mathrm{T} / \mathrm{T}$ & 15 & 26,31 & & & \\
\hline
\end{tabular}

Note: $p$ - reliability of differences of frequencies between genotypes by $\chi^{2}$ criterion; $p 1$ - reliability of differences of parameters relative to Hardy-Weinberg scale of genotypes equilibrium

At the same time patients were distributed depending on BA severity degree and detection of FTO and STAT6 genes polymorphism (Table 3).

Table 3 
Clinical-phenotypic characteristic of patients with bronchial asthma, combined with obesity, depending on FTO and STAT6 genes polymorphism and asthma severity degree

\begin{tabular}{|c|c|c|c|c|c|}
\hline & & & & $\begin{array}{c}\text { Patients with } \mathrm{BA}, \\
\text { combined with } \mathrm{Ob}(\mathrm{n}=57)\end{array}$ & \\
\hline & & & & & \\
\hline & & $\mathrm{T} / \mathrm{T}$ & $8(14,0)$ & $9(15,8)$ & $4(7,0)$ \\
\hline FTO & Genotypes & $\mathrm{T} / \mathrm{A}$ & $5(8,8)$ & $14(24,6)$ & $7(12,3)$ \\
\hline & & $\mathrm{A} / \mathrm{A}$ & $1(1,7)$ & $6(10,5)$ & $3(5,3)$ \\
\hline & & $\mathrm{C} / \mathrm{C}$ & $4(7,0)$ & $12(21,1)$ & $6(10,5)$ \\
\hline STAT6 & Genotypes & $\mathrm{C} / \mathrm{T}$ & $4(7,0)$ & $10(17,5)$ & $6(10,5)$ \\
\hline & & $\mathrm{T} / \mathrm{T}$ & $2(3,5)$ & $8(14,0)$ & $5(8,8)$ \\
\hline
\end{tabular}

Note: $n$ - number of observations

In the main group the light persisting bronchial asthma was detected in $21,0 \%$ of cases, middle severity - in $52,6 \%$ and heavy - in $27,2 \%$ of patients.

\section{Discussion of research results}

Last time more and more studies are devoted to the genetic predisposition to certain diseases. The last years' studies, including the full genomic analysis demonstrated the essential connection between obesity and rs9939609 single nucleotide polymorphism in the first intron of FTO fat gene, fat mass and obesity associated [17, 18]. But mechanisms of this gene influence still insufficiently studied. Alongside with it among genes - candidates of BA and atopy the researchers' attention is mostly fixed on the interleukin gene - 4 (IL-4). IL-4 is often called the "critical cytokine of inflammation". It is used to think, that STAT- 6 is activated by IL-4 and takes part in the induction of switching the synthesis of immunoglobulins to the synthesis of $\operatorname{IgE}$ and differentiation of Th2-cells [19]. There was also demonstrated the dependence for BA in $53 \%$ of cases and for obesity in $77 \%$, that indicates the genetic interconnection between these diseases. In parallel with it, at the association of BA and obesity the effect of "mutual complication" is fully realized that favors the heavier clinical course of asthma, worse control of the disease and bad patients' response to the treatment [20, 21].

Considering general clinical characteristics of examined patients (sex, age, disease duration), it must be noted, that groups didn't essentially differ by age structure. At the same time among patients wasn't observed any essential difference by gender. Thus the male share was $49,2 \%$, female $-50,8 \%$.

Analyzing the obtained data, it can be seen, that among patients with bronchial asthma of middle severity, combined with obesity, the percent of heterozygous $(T / A)$ and mutant carriers of $(A / A)$ of rs 9939609 polymorphism of FTO gene is 3 times higher than at the light course and 1,7 higher at the severe one. The analogous situation is observed at studying rs324011 polymorphism of STAT6 (C2892T) gene among this category of patients. The percent of heterozygous $(C / T)$ and mutant $(T / T)$ carriers of rs324011 polymorphism of STAT6 among patients with bronchial asthma of middle severity, associated with obesity is 3 times higher than at the light course and 1,8 times higher than at the severe one.

It was revealed $45,61 \%$ of heterozygous $(T / A)$ and $17,55 \%$ of mutant $(A / A)$ carriers of rs9939609 polymorphism of FTO gene and $35,09 \%$ of heterozygous $(C / T)$ and $26,31 \%$ of mu- 
tant $(T / T)$ carriers of rs324011 polymorphism of STAT6 (C2892T) gene among patients with bronchial asthma and obesity.

So, the determination of FTO and STAT6 genes polymorphism in patients with BA, associated with $\mathrm{Ob}$ may be considered as a marker of the more severe asthma course, probably, with a worse response to the treatment.

The prospect of further researches is the study of interconnections of FTO and STAT6 genes polymorphism in patients with bronchial asthma in the combination with obesity, with the effectiveness of the basic treatment and asthma controllability.

\section{Conclusions}

1. Among patients with bronchial asthma of middle severity and severe one, combined with obesity, the percent of heterozygous $(T / A)$ and mutant $(A / A)$ carriers of rs9939609 polymorphism of FTO gene and heterozygous $(C / T)$ and mutant $(T / T)$ carriers of rs324011 polymorphism of STAT6 is higher than at the light course.

2. The determination of FTO and STAT6 genes polymorphism in patients with BA, associated with $\mathrm{Ob}$ may be considered as a marker of the more severe asthma course, probably, with a worse response to the treatment.

\section{References}

[1] Fedoseev, G. B., Trofimov, V. I. (2010). "Many-sided” bronchial asthma. Russian allergological journal, 1, 40-52.

[2] Cherkashina, I. I., Nikulin, S. Yu., Logvinenko, N. I. et. al. (2009). Clinical and genetic analysis of patients with bronchial asthma. Pulmonology, 2, 77-81.

[3] Dixon, A. E., Holguin, F., Sood, A., Salome, C. M., Pratley, R. E. et. al. (2010). An Official American Thoracic Society Workshop Report: Obesity and Asthma. Proceedings of the American Thoracic Society, 7 (5), 325-335. doi: 10.1513/pats.200903-013st

[4] Choquet, H., Meyre, D. (2011). Genetics of Obesity: What have we Learned? Current Genomics, 12 (3), 169-179. doi: 10.2174/138920211795677895

[5] Asanov, A. Yu., Namazova, L. S., Pinelis, V. G., Zhurkova, N. V., Voznesenskaya, N. I. (2008). Genetic bases of bronchial asthma. Pediatric Pharmacology, 5 (4), 31-37.

[6] Scott, H. A., Gibson, P. G., Garg, M. L., Wood, L. G. (2011). Airway inflammation is augmented by obesity and fatty acids in asthma. European Respiratory Journal, 38 (3), 594-602. doi: 10.1183/09031936.00139810

[7] Barnes, P. J. (2013). Corticosteroid resistance in patients with asthma and chronic obstructive pulmonary disease. Journal of Allergy and Clinical Immunology, 131 (3), 636-645. doi: 10.1016/ j.jaci.2012.12.1564

[8] Barclay, L. (2008). Obese Patients With Asthma May Have Greater Risk for Hospitalization. Journal of Allergy and Clinical Immunology, 114, 635-648.

[9] Boulet, L.-P. (2012). Asthma and obesity. Clinical \& Experimental Allergy, 43 (1), 8-21. doi: 10.1111/j.1365-2222.2012.04040.x

[10] Sood, A., Qualls, C., Li, R., Schuyler, M., Beckett, W. S. et. al. (2011). Lean mass predicts asthma better than fat mass among females. European Respiratory Journal, 37 (1), 65-71. doi: 10.1183/09031936.00193709

[11] Gershon, A. S., Wang, C., Guan, J., To, T. (2010). Burden of comorbidity in individuals with asthma. Thorax, 65 (7), 612-618. doi: 10.1136/thx.2009.131078

[12] Ivashchenko, T. E., Kelembet, N. A., Ostankova, Yu. V., Baranov, V. S. (2009). Diseases and genes of predisposition. Bronchial asthma (Genetic passport - the basis of individual and predictive medicine). Saint Petersburg: NL, 134-153. 
[13] Melen, E., Granell, R., Kogevinas, M., Strachan, D., Gonzalez, J. R., Wjst, M. et. al. (2013). Genome-wide association study of body mass index in 23000 individuals with and without asthma. Clinical \& Experimental Allergy, 43 (4), 463-474. doi: 10.1111/cea.12054

[14] Sutherland, E. R., Goleva, E., King, T. S., Lehman, E., Stevens, A. D. et. al. (2012). Cluster Analysis of Obesity and Asthma Phenotypes. PLoS ONE, 7 (5), e36631. doi: 10.1371/journal.pone.0036631

[15] Boulet, L.-P., Boulay, M.-E. (2011). Asthma-related comorbidities. Expert Review of Respiratory Medicine, 5 (3), 377-393. doi: 10.1586/ers.11.34

[16] Global strategy for asthma management and prevention. National institutes of health. National Heart, Lung and Blood Institute (2014). Available at: http://www.ginasthma.org

[17] Fischer, J., Koch, L., Emmerling, C., Vierkotten, J., Peters, T., Bruning, J. C., Ruther, U. (2009). Inactivation of the Fto gene protects from obesity. Nature, 458 (7240), 894-898. doi: 10.1038/nature07848

[18] Zhao, X., Yang, Y., Sun, B.-F., Zhao, Y.-L., Yang, Y.-G. (2014). FTO and Obesity: Mechanisms of Association. Current Diabetes Reports, 14 (5), 486. doi: 10.1007/s11892-014-0486-0

[19] Godava, M., Vrtel, R., Vodicka, R. (2013). Stat6 - polymorphisms, haplotypes and epistasis in relation to atopy and asthma. Biomedical Papers, 157 (2), 172-180. doi: 10.5507/bp.2013.043

[20] Juel, C. T.-B., Ulrik, C. S. (2013). Obesity and Asthma: Impact on Severity, Asthma Control, and Response to Therapy. Respiratory Care, 58 (5), 867-873. doi: 10.4187/respcare.02202

[21] Chung, K. F., Wenzel, S. E., Brozek, J. L., Bush, A., Castro, M., Sterk, P. J. et. al. (2013). International ERS/ATS guidelines on definition, evaluation and treatment of severe asthma. European Respiratory Journal, 43 (2), 343-373. doi: 10.1183/09031936.00202013 